\title{
Editorial: Subjects and Citizens
}

\author{
LINCOLN GERAGHTY
}

In the last few months Britain has lived through several moments when the idea of being a citizen has been at the forefront of people's minds. In the space of twenty-four hours in July 2005 we experienced the jubilation of winning the right to host the 2012 London Olympics and felt the horror and shock caused by the terrorist attacks on the London transport network. Both events showed in stark contrast what being a citizen means for a nation in the twenty-first century: the inevitable coming together of a people to celebrate national success turned to bewilderment as Britons struggled to understand how fellow citizens could inflict such destruction on their own country. Questioning citizenship is now a daily occurrence in the national press as tabloids call for loyalty tests, immigrants to be repatriated, and tougher laws for extremists. The following six articles, written before the aforementioned events, tackle some of the very same issues that now trouble us. They address themes such as identity, nationality, confinement, attacks on liberty, citizenship, and being the subject of oppression. Analysing at a fundamental level the nature of being a subject or citizen, these papers challenge notions of dominant ideology and highlight the importance of self in the construction of identity and a harmonious citizenry.

Bronagh Clarke's 'Canadian Citizens as Postcolonial Subjects? Reading Robert Kroetsch's The Lovely Treachery of Words' explores the identity crisis of Canadian writers as they attempt to establish a cultural nationalism in the face of a declining British imperialism. What has it meant to be a Canadian citizen in the last thirty years after celebrating Canada's Confederation anniversary? Are Canadians 'postcolonial' subjects or are they merely part of Canada's 'settlerinvader' history? Clarke proposes that Robert Kroetsch's collected criticism provides an example of a prominent white-settler literary figure's response to issues of Canadian identity in a decolonising era, arguing that his essays are due for reassessment in the light of recent responses to postcolonial subjectivity which critique the coloniser/ colonised binary as used in 'settler-invader' contexts. Moving on from 
Canada to the United States, in Paul Edwards' 'Citizenship Inc.: Negotiating Civic Spaces in Post-Urban America' we are invited to explore the Disney Corporation's latest attempt at creating the ideal community: Celebration, Florida. Edwards takes us from the notion of the shopping mall as a 'private space', where ideas of social justice and the mixing of diverse peoples can be encouraged, to Disney's Celebration, where distinctions between public and private space have become increasingly blurred. As Edwards shows us, Celebration was publicised as the perfect community yet when faced with the possibility of dissent and political debate Disney preferred to exclude difference in favour of a homogenised citizenry. Edwards rightly points out that the consequences for such exclusion inevitably threatens democratic politics and the future building of diverse communities.

The boundaries and distinctions of citizenship are examined further by Joanne Hall in her essay 'The Wanderer Contained: Issues of "Inside" and "Outside" in Relation to Harold Grey's Little Orphan Annie and Marilynne Robinson's Housekeeping'. Here we see notions of the outsider within society represented by the figure of the female hobo. As Hall maintains, she not only violates perceived female gender norms, but, also 'performs an act of both transgression and trespass on the masculinised world of the male hobo'; the female hobo moves across the boundaries that codified the hobo as male, into an area where she is no longer confined by gender or the frames of categorisation. As traveller and transgressor, Hall shows how the female protagonists in Annie and Housekeeping step out of their framed worlds and into a spaceless, timeless realm that the reader would like to, but ultimately cannot, go. From the traveller to the homemaker, in James Walters" "Emotional Blood on the Undusted Carpets": The Citizen as Subject in Wife Swap' we see how the rise of reality programming on British television has coincided with a growth in attention afforded to ordinary members of the public. The citizen is central to this relatively new television format, subject to a myriad of emotions and traumas that test relationships and create schism. Yet Wife Swap is popular because it shows its subjects as real life, allowing viewers to sympathise with or hate those shown on screen. Walters highlights how the 'swap' format has provided the opportunity for individual citizens to become the central protagonists in a television drama. The power of this type of programming centres on the fact that as an audience we are drawn to the subject of the show 
(either the wife, husband or children) and through a constructed narrative are made to sympathise and ultimately remember them in our own day-to-day thoughts.

National identity and citizenship are called into question in the final two papers: Rayna Denison's '(Trans)National X-Factor: Patrick Stewart, Britishness and the Promotion of X-Men' and George Lipsitz's keynote address, 'The Culture of War'. Denison takes us through the promotion and critical reception of the $X$-Men film on its release in Britain in 2000. Taking Patrick Stewart as the focus for her investigation, she seeks to uncover the relationship between this 'calculated blockbuster film and one of its major stars'. Central to the promotion and financial success of the film Denison points to Stewart's 'Britishness', exemplified in his rolls on television and on the stage, and posits that his own national identity as British citizen was reconfigured on both national and international levels. As both the fictional Professor X and the real Patrick Stewart, Denison shows us how personal identity and public persona can change depending on the social contexts. In the final paper, written after Britain and America had gone to war with Iraq in March 2003, George Lipsitz makes a case for the Fourteenth Amendment of the American Constitution. In their attempts at fighting terrorism, America and Britain have risked curtailing the rights and freedoms of their respective citizenries. No longer are Americans protected by written laws. Instead, as Lipsitz maintains, they are subject to those who use fear tactics to assume and control political power. Serving to warn of the dangers of war made in the name of 'freedom' and 'extremism' Lipsitz reminds us that in these uncertain times we must try to focus on what truths we hold dear and what rights we have long cherished. If we give in to those fears then perhaps the 'culture of war' will be the only thing we will ever know. Lipsitz defines what a twenty-first century citizenship could be if we continue along those lines. As an addendum, the seventh article from Susan Araújo is an interview with the novelist Joyce Carol Oates. Oates discusses her latest novel, The Falls, and also highlights some of the themes and commonalities that link many of her most favourite and famous works.

The first six essays represent only a fraction of the papers presented at the 'Subjects/Citizens' symposium held at the University of Nottingham in December 2003, and I just want to acknowledge the tremendous range and quality of papers that, for lack of space, could not fit into this collection. I also want to thank my colleagues on the 
conference committee - Sophie Cartwright, Helen Taylor, Kerry Gough, Michael Duffy, Peter Urquhart, Catherine Nash, Ann McQueen, Alan Gibbs, Mark Jancovich, and Peter Ling - who made the symposium the critical success it was. In particular, I want to thank Rebecca Janicker and Susan Billingham for their efforts on the day, taking notes and offering advice, and Sharon Monteith for encouraging me to put together this special issue of Critical Survey. 